\title{
Szent István Pécsváradi oklevelének Sorlogys helynevéről és ami körülötte lehetett*
}

1. A pécsváradi bencés apátságot Szent István király alapította, az egykor vélhetően létező 11. századi oklevél azonban nem maradt fenn. A 11. századra datált Pécsváradi oklevél ma ismert szövegét a 13. században (1220 környékén) jegyezték le. Ez a 13. századi hamis irat sem örződött meg eredetiben, csak a 15. század elejéről származó többszörös átiratban. Ennek megfelelően az oklevelet a következőképpen datálhatjuk: $+1015 /+1158$ [1220 k.]/1323/1403/PR. (DHA. 1: 63). Ez az oklevél 41 Szent István-i falut említ. GYÖRFFY GYÖRGY szerint István király 11. századi oklevelébe a 13. századi hamisításkor a monostor javainak 11. századi összeírásából került be a legnagyobb szövegegység (GYÖRFFY 1969: 203, DHA. 1: 70). Úgy véli tehát, hogy a 11. századi hiteles alapítólevél mellett egy 11. századi összeíró oklevéllel is rendelkezett az apátság. A nyelvi elemzés során komoly nehézséget okoz azonban az, hogy ezek az oklevelek (a hiteles alapítólevél, illetve az összeíró oklevél) önállóan nem, csak a hamis oklevél 15. századi változatának részeként maradtak fenn. GYÖRFFY meglátása szerint ebből a 11. századi összeírásból felmérhetjük az apátság alapításkori birtokállományát, azaz a hamis alapítólevélben István adományaként megnevezett birtokokat valósnak fogadhatjuk el. A 41 megszámozott falu közül csupán a hetedikként megnevezett, Baranya megyei Kölked (Kulkedý) települést nem tartja alapításkori adománynak, ez tudniillik csak 1057-ben került az apátság tulajdonába (Gy. 1: 331). A többi 40 falu István általi adományozása mellett szól például, hogy a Szent István utáni uralkodók (Domoszló herceg, Szent László és Vak Béla) adományai jól elkülönülve szerepelnek a hamis szövegben. Az uralkodók adományainak ilyesfajta elhatárolása megengedi azt a következtetést, hogy a Szent István-i adományként megnevezett birtokokat valóban az apátság alapítójától származóknak tekintsük. (GYÖRFFY 1977: 235-237, DHA. 1: 77-80.)

GYÖRFFYvel részben egyetértve, ugyanakkor óvatosabban eljárva egy korábbi előadásomban ${ }^{1}$ én mindössze annyit feltételeztem, hogy az oklevél Szent István adományait megnevező helyneveit 11 . századiaknak tarthatjuk. Jelenlegi tudásunk szerint ezt legfóképpen az támogatja, hogy a fennmaradt irat szövegezése emlékeztet a Szent László korából származó összeíró oklevelekére. Amennyiben az oklevél helyneveit nem István korára, hanem a 11. századra datáljuk vissza, Kölked falu nevét is figyelembe vehetjük a többi 40 falu nevének említésével együtt. Ez annál is inkább indokolt, mert az 1057. évi oklevél révén, amely arról számol be, hogy Kölked csak a század közepén vált apátsági birtoklású területté, sokkal biztosabban nyilatkozhatunk a Kölked helynév 11. századi létezéséröl, szemben azokkal a nevekkel, amelyek jelenlegi ismereteink szerint a 11. századra vonatkozólag csak a hamis oklevélben maradtak fenn. Ha elfogadjuk ennek a kijelentésnek a jogosságát, a Pécsváradi oklevél révén a forrásszegény 11. század mintegy 130 helynévi

\footnotetext{
* Készült az MTA-DE Magyar Nyelv- és Névtörténeti Kutatócsoport programja keretében.

${ }^{1}$ A Magyar Nyelvtudományi Társaság Debreceni Csoportjának felolvasó ülésén (2019. február 28.)
} 
szórvánnyal gazdagodhat: a birtokok nevein túl ugyanis a határleírásukban szereplő helyneveket is itt vehetjük figyelembe.

2. Mostani tanulmányomban az alapítólevél helynévtörténeti forrásértékének a kérdésköre után (amit tehát egy korábbi elöadásomban fejtettem ki) az oklevél Sorlogys helyneve alapján a nyelvemlék nyelvtörténeti forrásértékével kívánok foglalkozni. A kiindulópontot GYÖRFFYnek az az elképzelése adja, hogy a hamis oklevélben a Baranya megyei Hird falu leírásában (,tricesimasecunda Hirig nominatur, que ab oriente terminatur Sorlogys, ab austro Sedfev, ab occidente Nogvt et Curtuelfa, a septemtrione Hudus", DHA. 1: 75) szereplö, a sarló köznévből alakult helynév az ősmagyar kor hangállapotbeli sajátosságait tárja elénk, és az István korában beszélt magyar nyelv néhány jellemzőjére is rávilágít. ${ }^{2}$ GYÖRFFY GYÖRGY véleménye szerint a hamis oklevél Sorlogys nevében a sarló szavunk ősmagyar, illetve bolgár-török sorlogh alakja örződött meg. A név hangalakjának alakulásmódját a Szántó névvel állítja párhuzamba, amely a görög nyelvü Veszprémvölgyi adomány-

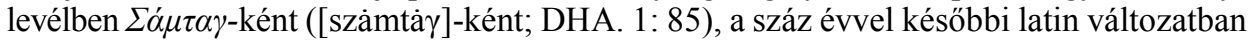
pedig Zamtou-ként (DHA. 1: 366) szerepel. A Sorlogys szórványt tehát a Baranya megyei Sarlós településnév (ma Magyarsarlós) (palato)veláris zöngés spiránst tartalmazó változatának tekintve sorolja az ősmagyar koriak közé (GYÖRFFY 1977: 236, 1988b: 21).

Ez a felismerés is nagyban hozzájárult ahhoz, hogy GYÖRFFY GYÖRGY úgy vélekedjen a hamis oklevél megírásához felhasznált, de ma már nem létező összeíró oklevélről, hogy annak jelentős része vitathatatlanul a 11. század végén, Szent László korában készült ugyan, de feltehető, hogy egyes szövegrészleteit már István koronázása előtt is lejegyezték (DHA. 1: 70; GYÖRFFY 1988b: 22, 2001: 99). ${ }^{3}$ A hamis oklevél keltezési formulája is azt mondja, hogy a határok kijelölése már István koronázása elött megtörtént (DHA. 1: 70). KRISTÓ GYULA a keltezési formula szokatlan formai jegyei, illetve problémás tartalma mellett a korabeli környezet ismertetésével is hitelesen cáfolja a korai határkijelölés lehetöségét. István az apátság környékén élő fekete magyarokat ugyanis csak 1008-ban győzte le fegyveres harcban, ezért a megjelölt időszakban Pécsvárad környékén még nem alapíthatott monostort, és ennek megfelelöen a birtokait sem jelölhette ki. A birtokösszeírás korai lejegyzésével kapcsolatban az sem tisztázott továbbá, hogy ki írta volna ezt az oklevelet a német császári kancellária írnokának, Heribert C-nek a Magyarországra érkezése elött. (KRISTÓ 2000a: 315.)

A mai Magyarsarlós Pécstől délkeletre helyezkedik el Baranya vármegyében (FNESz. Magyarsarlós, BMFN. 1: 842-845). A Veszprémvölgyi adománylevél a falut a veszprémvölgyi apácák tulajdonaként nevezi meg (DHA. 1: 85, 366). Az apácák 1224-ben bérletbe

${ }^{2}$ GyÖRfFy GyÖRGY a Pécsváradi alapítólevélben tizennyolcadik faluként említett, véleménye szerint a Baranya megyei Szellő faluval azonosítható Scedluc (DHA. 1: 74) szórványt szintén az ösmagyar koriak közé sorolja (GYÖRFFY 1977: 236, 1988b: 21).

${ }^{3}$ Az oklevél helyneveinek a vallomását több évtizeddel korábban SZENTPÉTERY IMRE is figyelembe vette az oklevél keletkezési idejének a meghatározásakor. Ö azonban GYÖRFFYvel szemben MELICH JÁNOS alapján - számolva ugyan az átírásoknak a névalakokra gyakorolt hatásával - úgy véli, hogy az oklevél Szent István-kori előzményének ellentmond az, hogy nincs benne egyetlenegy 11. századra utaló névalak sem. A Chorozt, Zeru, Noghutholmu, Kulkedy stb. neveket 12. századinak vagy 13. század elejinek, a Balwanus mege, Rowozluk stb. neveket pedig a többszörös átírás következményeként még fiatalabb névalakoknak tartja (SZENTPÉTERY 1918: 15, 36). 
adták a pécsváradi apátságnak (H. 7: 10, Gy. 1: 376). A Pécsváradi oklevélben még nem (birtok)adományként, hanem egy adományozott terület határpontjaként szerepel, amenynyiben valóban erről a helyről szól az oklevél. A Pécsváradi oklevél 17. és 18. századi átiratában az itt elemzett alakra erősen emlékeztető Sorlongis és Sarlongis név szerepel (DHA. 1: 237). Egy ugyanabból az évből (1403) származó oklevél, mint amelyik évből a Pécsváradi oklevél legrégebbi szövegét ismerjük, Sarlós és Sevenye $\sim$ Zsemenye határát leírva Sarlos-ként említi a Baranya megyei települést (DHA. 1: 178). A 12. század elejéről származó Veszprémvölgyi adománylevél hiteles latin változatában Serlous (DHA. 1: 366) tünik fel (a település többi adatához 1. a KMHsz. 1. Sarlós szócikkét).

A Pécsváradi alapítólevél a Baranya megyei Hird falu keleti határpontjaként említi a Sorlogys nevü helyet, ahogyan erre már fentebb utaltam. A névalaknak Sarlós faluval való azonosíthatóságát GYÖRFFY az után a felismerés után látta igazoltnak, hogy az alapítólevél több faluból álló birtoktömbökről tesz említést. Véleménye szerint Sorlogys nem Hird falunak, hanem az előtte említett Suene falunak (a mai Zsemenye pusztának, amely ma Nagykozár településhez tartozik, vö. Gy. 1: 409, BMFN. 1: 822-825) a déli szomszédja, és ilyen módon Sarlós faluval azonos (GYÖRFFY 1977: 236). GYÖRFFY GYÖRGY déli határpontról beszél Sorlogys kapcsán, pedig az oklevél e nevet Hird falu keleti részére helyezi (que ab oriente terminatur Sorlogys, DHA. 1: 75). A második katonai felmérés alapján lokalizálva a helyeket azonban esetleg mégis GYÖRFFY vélekedését alátámasztó tényekre bukkanunk: míg Sarlós Hird falunak egyértelmüen a déli szomszédja, addig az oklevélben említett Suené-hez (a mai Zsemenye pusztához) viszonyítva inkább keletre helyezkedik el, igaz, erőteljesen délkelet irányában. A Hird határleírásában északra helyezett Hódos is talán Zsemenye pusztához és nem Hirdhez viszonyítva tekinthetỏ északi határpontnak (MKFT.). A Pécsváradi alapítólevélben, illetve GYÖRFFYnél jelentkező eltérő tájolás a fentebb mondottakon túl vélhetően a téli és a nyári időben végzett határjárás különbségeire is visszavezethetö (vö. GYÖRFFY 1956: 410-411). Egyelöre csak a helyek lokalizálására fókuszálva talán elfogadhatjuk GYÖRFFYnek az oklevél határleíró részeiről mondott gondolatait, azt tudniillik, hogy az oklevélíró nem egyes falvakról, hanem birtoktömbökröl tesz említést, de ez nem tükrözödik egyértelmüen a szövegben.

3. Ha nyelvi oldalról további adalékokkal tudjuk alátámasztani, hogy a Pécsváradi alapítólevél névalakja valóban a Baranya megyei Sarlós helynév legrégebbi ismert írott formája, ahogyan azt GYÖRFFY véli, akkor ez meggyőzően megtámogatná a Szent Istvánkori hiteles oklevél, illetve a 11. század végi összeírás létezését is. Emellett pedig azt is igazolná egyúttal, hogy a hiteles oklevél nyomán készült hamis oklevélben a nevek lejegyzésében is kereshetünk 11. századi, illetve század eleji nyomokat (és nem ősmagyar koriakat, ahogyan azt GYÖRFFY gondolja), azaz az alapítólevelet nemcsak mint helynévtörténeti forrást, hanem mint nyelvtörténeti forrást is figyelembe vehetnénk a 11. század nyelvi jellemzésekor. A 12. század elején a Veszprémvölgyi adománylevél latin változatában ugyanis már Serlous alakban szerepel a településnév (DHA. 1: 366).

GYÖRFFY GYÖRGY az Árpád-kori Magyarország történeti földrajza címü sorozatnak a Baranya vármegyét tartalmazó első kötetében Sarlós szócikke alatt még nem tesz említést a Pécsváradi alapítólevél névalakjáról (Gy. 1: 376). ${ }^{4}$ A TESz., az EWUng. és a WOT. sem

\footnotetext{
${ }^{4}$ Szent István királyról írt monográfiájában találtam az első megjegyzést a Sorlogys szórvány azonosításával kapcsolatban (GYÖRFFY 1977: 236).
} 
említi ezt a helynevet a sarló szócikkében. A történeti földrajz alapján készült helynévszótár, a Korai magyar helynévszótár lapjain azonban már feltünik a hamis oklevél névadata is (KMHsz. 1. Sarlós a.). A KMHsz.-hez hasonlóan korábban a FNESz. is megemlíti ezt a korai időszakra datált adatot Magyarsarlós szócikkében.

3.1. A Sarlós helynevek alapjául szolgáló sarló köznév etimológiájának részletes bemutatásától ezúttal eltekintek, ezt ugyanis néhány éve a WOT. szerzői már megtették (2: 697-698; vö. még TESz., EWUng. sarló). ${ }^{5}$ A sarló köznév a honfoglalás elötti csuvasos jellegü török jövevényszavaink egyike (vö. pl. BÁRCZI 1958a: 73, 77; BENKÖ 1967: 280-282; ZSILINSZKY 2005: 202; GERSTNER 2018: 252). A legvalószínübbnek az tünik, hogy a sarló

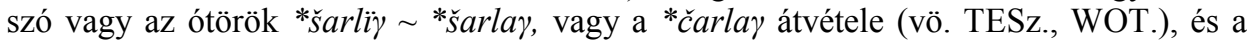
magyar nyelvbe sorlo $\gamma$ formában adaptálódhatott.

A Sorlogys szórványt a Sarlós név egy korábbi változatának tartva a korai ómagyar kori hangzását [sorloyus]-ként adhatjuk meg. Amennyiben valóban Sorlogys szerepel az oklevélben, feltételezhető, hogy a képző előtti magánhangzó y jelölése íráshiba következménye lehet $u$ vagy $v$ helyett, szabályos hangváltozással ugyanis a [sorlogis]-ból nem tudjuk megmagyarázni a Sarlós formát. ${ }^{6}$ Egy [sorloyus] hangzású településnév akkor jöhetett létre, amikor az alapjául szolgáló közszó még sorlo $\gamma$ alakú volt. Később, amikor a szóban a veláris zöngés spiráns vokalizációja következtében már diftongust (sarlou) vagy ebből alakult hosszú magánhangzót (sarló) ejtettek, a közszóból alakult településnév is [Sarlous] vagy [Sarlós] hangzású lett. Magyarsarlósnak a Veszprémvölgyi adománylevélből származó 12. századi Serlous (DHA. 1: 366), illetve az 1224/399-es Sarlous (KMHsz. 1: 237) adata is igazolhat egy ilyen lefolyású változást, a névalakok lejegyzésében az ou jel ugyanis diftongust (vagy ebből alakult hosszú magánhangzót) jelölhet.

3.2. Nyelvi oldalról közelítve a kérdéshez azt mondhatjuk, hogy a Sorlogys névforma - íráshibát feltételezve - lehet a Sarlós név egy korábbi változata. Ezt tovább erősítheti a Pécsváradi oklevélnek egy 1403-ból átiratban fennmaradt oklevéllel való összevetése. Ebben az oklevélben megtaláljuk Sarlós és a vele határos Zsemenye Sevenye határleírását. Zsemenyét - ahogyan arról már korábban szóltam - Hird falu előtt említi a Pécsváradi alapítólevél, és GYÖRFFY úgy véli, hogy az oklevélben Hird határában szereplö Sorlogys (= Sarlós) valójában Zsemenye szomszédságában található. Ha összevetjük a két oklevél határleírását, akkor két egyező pontot is találunk, ami valamelyest utalhat arra, hogy a Pécsváradi oklevél névalakja valóban a Sarlós névvel azonosítható. Ez a két határpont a Nagy-út (+1015/+1158 [1220 k.]/1323/1403/PR.: Nogvt, DHA. 1: $75 ;+1058 / 1300 / / 1403$ : magnam viam, DHA. 1 : 178) és a Hódos víznév (+1015/+1158 [1220 k.]/1323/1403/PR.: Hudus, DHA. 1: 75; +1058/1300//1403: Hodos, DHA. 1: 178).

\footnotetext{
${ }^{5}$ Sarló nevü településsel Bars (Gy. 1: 470, TóTH 2001: 231-232) és Gömör megyében (Cs. 1: $145)$ is találkozunk.

${ }^{6}$ Az oklevél fényképmásolatához egyelöre nem jutottam hozzá, a IX. Bonifác pápa 1403. évi bullájának egykorú másolata ugyanis, amelyből az alapítólevél legrégebbi szövegét ismerjük, a Vatikáni Titkos Levéltárban lelhető fel (vö. DHA. 1: 63).
} 
4. Mivel a Pécsváradi oklevél elemzett szórványa lehet a Pécs közelében lévő mai Magyarsarlós település nevének egyik legkorábbi fennmaradt adata, ezért e névalak tárgyalásakor arra a kérdésre is kitérek, hogy a Sarlós névforma hogyan viszonyul a Veszprémvölgyi

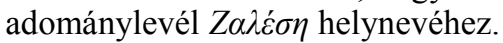

A Veszprémvölgyi adománylevél görög nyelven íródott Szent István vagy apja, Géza korában, de csak 1109-ből maradt fenn a szövege, amikor Kálmán király idején az eredeti görög szöveg másolata alá ugyanarra a hártyára az oklevél latin nyelvü változatát is lejegyezték. Az oklevelet görög és latin nyelven tartalmazó hártyából két példány maradt fenn: egy pecséttel rendelkező és egy anélküli (vö. ÉRSZEGI 1988: 4, DHA. 1: 81, SZENTGYÖRGYI 2012). Korábban egykorú oklevélpároknak tartva öket, az elemzések során a pecsételetlen példány háttérbe szorult a pecséttel rendelkező mellett (vö. HÓMAN 1911: 123). FEJÉRPATAKY volt az első, aki a latin szöveget vizsgálva felfigyelt arra, hogy a két változat nem feleltethető meg szó szerint egymásnak, ráadásul a pecsételetlen példány latin szövege jobban visszaadja a görög szöveg tartalmát (1885: 12, 1892: 21-40). Ezen a kutatási vonalon továbbhaladva néhány évvel később HÓMAN BÁLINT mondta ki, hogy csak a pecsételetlen hártya latin szövegét tarthatjuk hitelesnek, a pecsétes példány latin szövege pedig 13. századi hamisítvány (1911, 1917: 242; vö. DHA. 1: 378). FEJÉRPATAKYt követve a görög szövegeket GYOMLAY GYULA vette alapos vizsgálat alá, és vonta le ugyanazt a következtetést, amelyet a latin szöveggel kapcsolatban tíz évvel később HóMAN BÁLINT is megállapított: a pecsét nélküli példány görög szövege a hiteles, míg a másik, a pecsétet is tartalmazó hártya görög nyelvű oklevele egy görögül alig tudó személy silány másolata lehet csupán. GYOMLAY vélekedése szerint a tévesztések mögött akár szándékosság is meghúzódhat (1901: 22-44). ${ }^{7}$

Az oklevél latin nyelvü változata nem szó szerinti fordítása a görögnek, már csak azért sem, mert az egy évszázad alatt bekövetkezett változások rögzítése is fontos szempont volt a lejegyzésekor: „Vetus autem privilegium iuxta linguam auctoris monasterii grece scriptum ideo adnotavimus, ut ex concordia veteris et novi cognosceretur certitudo veritatis; licet iuxta investigacionem Quin(queec)clesiensis episcopi apposita sint quedam in novo, que non inveniuntur in veteri, $<$ et $>$ que sancte ecclesie accreverunt in processu temporis (DHA. 1: 367). Magyarul: „A monostor kezdeményezőjének nyelve szerint görögül íródott régi privilégiumot azért írattuk hozzá, hogy a régi és az új összehasonlításából biztosan kiderüljön az igazság. Hiszen a pécsi püspök vizsgálata szerint az újba be lettek véve azok is, amelyek nem találhatók meg a régiben, vagyis azok, amelyekkel gyarapodott a szent egyház az idők folyamán.” (ÉRSZEGI 1997: 125, vö. ÉRSZEGI 1978: 32.) A hiteles latin és görög szöveg eltéréseit többen is részletesen tárgyalták már (vö. pl. GYOMLAY 1901: 21-22; HÓMAN 1911: 127, 1917: 225-230; CZEBE 1916: 78-93; KUMOROVITZ 1984: 8-9), én magam e helyütt most pusztán a görög és a latin nyelvű oklevél témánk szempontjából fontos különbségére kívánok kitérni. A görög oklevelében az ado-

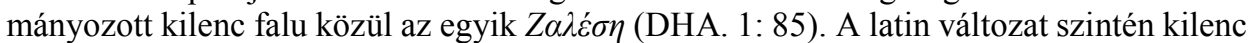

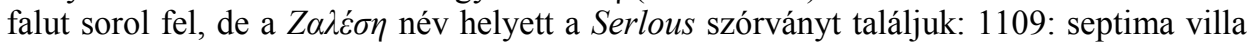
est Serlous (DHA. 1: 366), +1109 [1280-95]: item dedit villam Sorlous (DHA. 1: 380). Ez a Sarlós ugyanaz a Baranya megyei település (a mai Magyarsarlós), mint amelyik talán a Pécsváradi oklevélben határpontként szerepel (DHA. 1: 75).

\footnotetext{
${ }^{7}$ KARÁCSONYI JÁNOS a Szent István okleveleiről írt monográfiájában például még a korábban hitelesnek hitt görög szöveget adja közre (1891: 26-27). Az oklevél további kiadásaihoz 1. DHA. 1: 81.
} 
Az imént idézett oklevélrészlet alapján arra gondolhatunk, hogy az alapításkori adományok alapvetően megmaradtak, csak a birtoklásuk mértékében történtek esetleg változások (vö. KARÁCSONYI 1891: 37). Ezért azt a feltételezést talán elvethetjük, hogy Sarlós az apácakolostor új birtokadományaként szerepel a latin szövegben, a Z $\alpha \lambda \varepsilon ́ \sigma \eta$ birtoklása pedig a két oklevél keletkezése közti száz évben megszünt. Ebben az esetben Sarlós birtok státuszát minden bizonnyal jobban hangsúlyozná a latin oklevél, és nem a többi (a görög változatban is szereplö) birtok között említené meg (vö. DHA. 1: 366).

4.1. A szakirodalom a görög oklevélben említett helyet a latin renováció Serlous szórványa alapján szinte egyöntetűen a Baranya megyei Sarlóssal, a mai Magyarsarlóssal azonosítja (vö. pl. HORVÁT 1834: 92; KARÁCSONYI 1891: 37; FEJÉRPATAKY 1892: 36; HÓMAN 1911: 126, 131; MIKOS 1935: 118; PAIS 1939: 37-40; Gy. 1: 376; HECKENAST 1970: 118; KRISTÓ 1976: 71, 1993: 201, 2000b: 15; GYÖRFFY 1977: 321, 1988a: 47-48, 1994: 20, 1997: 123; KUMOROVITZ 1984: 9). Ismereteim szerint egyedül HOLLER LÁSZLÓ kérdőjelezte meg a két hely azonosságát (2012: 53). Ezt a véleményét föként a neveknek az oklevelekben elfoglalt helyére alapozza, a Z $\alpha \lambda \varepsilon ́ \sigma \eta$ és Serlous nevek ugyanis nem ugyanolyan sorrendben, nem ugyanazoknak a településeknek a nevei után vannak megemlítve a két oklevélben (2012: 54). ${ }^{8}$

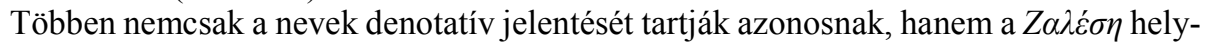
nevet a latin oklevélben szereplö Sarlós név (egy korábbi hangállapotot tükrözö) görög betüs lejegyzésének tekintik (vö. HORVÁT 1834: 92, FEJÉRPATAKY 1892: 36, vö. KARÁCSONYI 1891: 37). HÓMAN BÁLINT például a görög oklevél helynevének [Saleszé] olvasatot adva, és ezt a törökböl való sarló szavunkból származó Sarlós helynév változatának tekintve teremt kapcsolatot a két név között (1911: 132). BÁRCZI GÉZA a Veszprémvölgyi adománylevél, illetve a latin renovációs oklevél helyneveit egymás mellé állítva kérdőjelesen ugyan, de az általunk elemzett neveket is példaként idézi a tővégi magánhangzók egy évszázad alatt bekövetkezett változásának a bemutatásához (1958b: 22, vö. 1951: 76).

GYÖRFFY GYÖRGYnek az Árpád-kori Magyarország történeti földrajza címü munkájában a szócikkek szerkezetét a denotátumok határozzák meg, azaz egy-egy denotátum különböző nevei egy szócikkben szerepelnek akkor is, ha köztük lexikális vagy morfológiai különbség van, illetve akkor is, ha eltérő nyelvekből származnak. Ezek alapján nehéz állást foglalni abban a kérdésben, hogy GYÖRFFY hogyan vélekedik a két helynév azonosságáról (Gy. 1: 376). Az e munkát forrásként felhasználó Korai magyar helynévszótár szerkesztői azonban a Sarlós szócikk alatt közlik az adománylevélben szereplő nevet, a magyar név görög nyelvü változataként szerepeltetve (KMHsz. 1: 237). Ennek a történeti helynévszótárnak ugyanis az a jellemző szócikkszerkesztő elve, hogy csak azokat az adatokat sorolják egyazon szócikk alá, amelyeknek amellett, hogy azonos helyet jelölnek, a morfológiai szerkezetük is megegyezö (KMHsz. 1: 9). GYÖRFFYnek a helynevekre vonat-

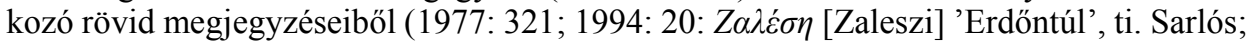

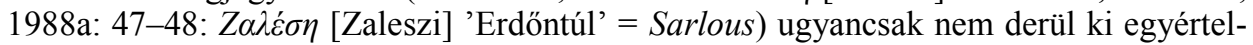
müen, hogy a két névnek csak a denotatív jelentését tartja azonosnak, vagy - ahogyan HÓMAN BÁLINT - a görög betűkkel lejegyzett névben a Sarlós név korábbi alakját látja. Ugyanakkor a szerző több tanulmányában is véleményt alkotott a Baranya megyei Sarlós

\footnotetext{
${ }^{8}$ A birtokok felsorolásának sorrendjéhez vö. GYOMLAY 1901: 21, CZEBE 1916: 79-80, HómAN 1917: 132-136.
} 
név foglalkozásnévi eredetéröl (GYÖRFFY 1972: 286, 1977: 240, 1994: 17), ez pedig azt

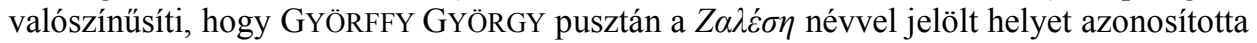
a Baranya megyei Sarlóssal. Nyelvileg a Zaleszi-t nem a Sarlós változatának, hanem szláv nyelvi szinonimájának tartja (vö. GYÖRFFY 1997: 123).

4.2. Egyes oklevélkiadások, illetve oklevél-magyarázó munkák a név végi magán-

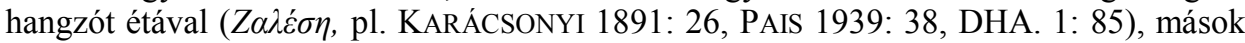

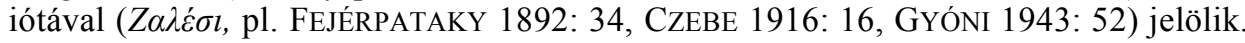
$\mathrm{Az}$ 1109. évi oklevél két példányának (a hamisnak és az eredetinek) a fényképmásolatát megnézve étát találunk az oklevélben (DF. 11,11/1). Ezek a görög betük (az éta és az ióta) mások mellett egyaránt az $i$ hang jeleként voltak használatban a görög nyelvü forrásokban, az és é hangokat ugyanakkor epszilonnal ( $\varepsilon$ ) jegyzik (GYÓNI 1943: 10, 185, 209; OLAJOS 2014: 9). A görög betűkkel lejegyzett szórvány latin betűs átírása a szóvégi magánhangzó tekintetében ennek megfelelően már egységesebb képet mutat, a legtöbben $i$-vel írják át (vö. BÉKEFI 1907: 58; GYÓNI 1943: 52; GYÖRFFY 1977: 321, 1988a: 47-48, 1994: 20; KUMOROVITZ 1984: 9; MORAVCSIK 1984: 80; KRISTÓ 1993: 201; MORAVCSIK-OLAJOS 1999: 118), de van ellenpélda is: HORVÁT ISTVÁN (1834: 92) és JERNEY JÁNOS (1854: 116) például a szórvány olvasatát [Zalese], HómAN BÁLINT (1911: 126, 131) [Saleszé], KRISTÓ GYULA (2000b: 15, 19-20) pedig [Zalesé] formában adja meg.

A kezdőhang olvasatában sincs teljes összhang, ami a név különböző értelmezéseivel

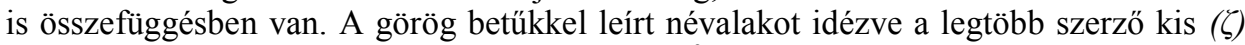
vagy nagy $(Z)$ dzétával jelöli a név kezdőhangját, ${ }^{9}$ és ezt a $z$ hang jelének tekinti (vö. például KARÁCSONYI 1891: 26, CZEBE 1916: 16, PAIS 1939: 38, GYÓNI 1943: 52, MORAVCSIK 1984: 80, DHA. 1: 85), de a kezdőbetü mögött $s$ (HÓMAN 1911: 132), cs/c (PAIS 1939: 38-40) vagy zs (MIKOS 1935: 118) hangot feltételező munkákkal is találkozunk.

Ránézve a Veszprémvölgyi adománylevél hiteles és hamis példányának fényképmásolatára ugyanakkor nem lehetünk biztosak abban, hogy a lejegyzett betü valóban dzéta:

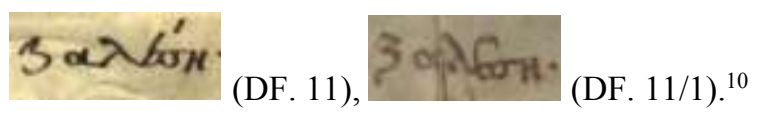

Az elemzett név közelében van a hiteles oklevélben két másik településnév, amelyek alapján úgy látszik, hogy az oklevélíró az imént bemutatottól eltérő módon írja ezt a görög betüt; az egyik a Gerencsér, a másik pedig a Csitény településnév:

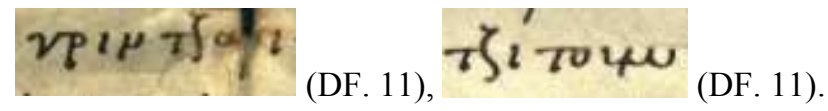

\footnotetext{
${ }^{9}$ Az általam ismert munkák közül a görög kezdőbetű lejegyzésében megmutatkozó egységes képet csak KARÁCSONYI JÁNOS (1891: 37) és FEJÉRPATAKY LÁSZLÓ (1892: 34) töri meg, ők ugyanis nagy szigmával $(\Sigma)$ jegyzik a kezdöhangot. KARÁCSONYI JÁNOS ugyanakkor a szöveget közölve már dzétával kezdi a név lejegyzését (1891:26).

${ }^{10}$ A Veszprémvölgyi hiteles adománylevél jelzete DF. 11, a hamis példányé pedig DF. 11/1.
} 
Az elemzett szórványban alkalmazott jelölésmód sokkal inkább emlékeztethet bennünket az $s z$ és a $z$ hang jeleként használatos $z$ betü „lehúzott szárú” (3) változatára (vö. KOROMPAY 2018: 87). Elképzelhetőnek tartom, hogy a lejegyző itt a $z$ hangot nem egy görög betüvel, hanem latin, illetve magyar nyelvü nyelvemlékeinkben használatos jellel írta fel a hártyára: ${ }^{11}$

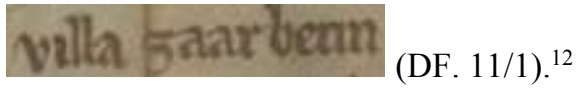

A jelek hasonlósága alapján is kérdéses azonban, hogy a 12. század eleji (1109) görög nyelvü hiteles változatot lejegyző írnok honnan ismerhette ezt a latin nyelvü oklevelekben csak a 13. századtól alkalmazott jelet. A vélhetően 13. századi hamis példányban a Csitény településnévben is a lehúzott szárú $z$-hez hasonló jelet találunk:

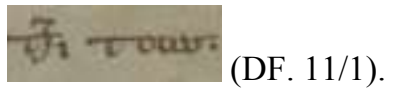

A Gerencsér helynév említése jó példa lehet a hamis változat „szabályos” dzétájának bemutatására:

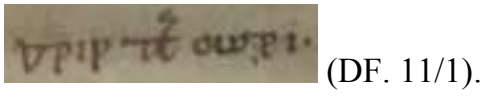

Ebből a paleográfiai kitérőből a bizonytalanságok ellenére talán annyi mégis feltételezhető, hogy a görög oklevélben szereplő szórvány latin kezdőbetüje a $z$ lehetett, amelyet „szabályos” módon a görög dzétával kellett volna lejegyezni. Az is elöfordulhatott ugyanakkor, hogy a lejegyzőnek az esetleg előtte lévő latin betűs jegyzetektől függetlenül is gondjai lehettek a dzéta lejegyzésével, és ezért hol így, hol úgy írta azokat. Ezt erősítheti meg a hiteles görög oklevélből származó másik példa, amely nem a helynevek köréből való:

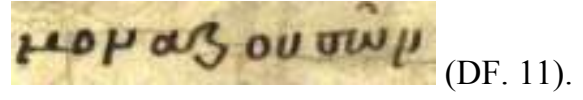

A $z$ betü leggyakrabban az $s z$ és a $z$ hangok jeleként szerepel nyelvemlékeinkben, de az $s, z s, c$ vagy $c s$ hangok lejegyzésére is használatban volt (KOROMPAY 1918: 87, vö. KNIEZSA 1952: 191). A $\zeta$ is leginkább a $z$ jele, emellett pedig a $z s$ és $s$ hangot jelölték még vele ritkábban. Az olvasati lehetőségek között még felmerülő $c$ és $c s$ hangok a görög emlékekben egyöntetüen egy tau és egy dzéta kapcsolata $(\tau \zeta)$ révén jelennek meg (GYÓNI 1943: 187, 210). Ha két betü (a latin $z$ és a görög $\zeta$ ) keresztmetszetét nézzük, akkor a név

\footnotetext{
${ }^{11}$ A görög oklevél $\beta$ betűjének hangjelölési sajátosságait vizsgálva CZEBE GYULA is arra a következtetésre jutott, hogy ,a magyar kiejtés megközelítése kedvéért a görög betűk modern hangértéke rovására engedmények történtek a latinos írásmódnak" (1916: 45).

${ }^{12}$ A hamis Veszprémvölgyi adománylevél latin renovációjának Szárberény helyneve. A 1109. évi hiteles változatban nem a lehúzott szárú $z$ jelenik meg (DF. 11).
} 
korabeli hangzásának megadásakor a $z$ vagy esetleg az $s, z s$ hangok jöhetnek leginkább számításba.

4.3. A továbbiakban a felmerült olvasatokat, illetve etimológiai magyarázatokat veszszük sorra, az után kutatva, hogy a $z / \zeta$ betük hangjelölési sajátosságain túl vannak-e egyéb fogódzóink, amelyek alapján valamelyik magyarázat mellett le tudjuk tenni a voksunkat. A korszak helyesírási sajátosságait mérlegelve a $z$-s olvasat tünik ugyan a legvalószínübbnek, de a másik három lehetőség $(s, z s, c / c s)$ sem zárható ki.

4.3.1. Korábban már említettem, hogy a névnek van olyan értelmezése, amely szerint a görög oklevél helyneve a latin oklevélben szereplő Baranya megyei Sarlós név egy korábbi hangállapotot tükröző változata (vö. HORVÁT 1834: 92, KARÁCSONYI 1891: 37, FEJÉRPATAKY 1892: 36; vö. BÁRCZI 1951: 157, 1958b: 22). Az a körülmény, hogy az eredeti görög oklevélnek körülbelül száz évvel később (1109) elkészült a latin nyelvü változata, kiváló lehetőséget teremt arra, hogy a bennük szereplő névalakok egymás mellé helyezése révén az egy évszázad alatt bekövetkezett hangváltozásokat regisztrálhassuk. Ezt viszont bizonyos mértékig gátolja a görög oklevél fennmaradási módja: a szöveget csak másolatban ismerjük, ahogyan 1109-ben Könyves Kálmánnak az apácák adományait megerősítő oklevelében lejegyezték. Nem lehetünk tehát teljesen biztosak abban, hogy a 12. század eleji másolatból ismert formák az eredeti oklevél helyneveivel minden részletében megegyező képet mutatnak. Bár az a körülmény, hogy ebben az esetben görög (és nem latin) szöveg másolásáról (és nem átírásáról) van szó, talán valószínübbé teszi, hogy hűen másolták az eredetit. A helynevek egy jelentős részénél valóban megfigyelhető, hogy a görög oklevélbeli alak nyelvtörténeti szempontból korábbi a latin változatban szereplönél (vö. HOFFMANN 2009: 20, HOFFMANN-RÁCZ-TóTH 2018: 30-31), az elemzett nevek esetében azonban ez nem ennyire magától értetődő. Feltételezhető, hogy a lejegyzőnek nehézséget okozott a magyar helynévrendszer elemeinek görög betükkel való lejegyzése (vö. HOFFMANN 2009: 20, HOFFMANN-RÁCZ-TÓTH 2018: 30), KARÁCSONYI JÁNOS például a lejegyző hibázásával magyarázza a Sarlós helynévnek a görög oklevélben megjelenő alakját (1891: 37).

Egy efféle tévesztést természetesen nemigen áll módunkban egyértelműen igazolni vagy cáfolni, de az mindenesetre gyanút ébreszthet bennünk, hogy a további nyolc adományozott falu nevének a görög oklevélbeli változata egyértelmüen megfeleltethetö a latin nyelvű példány egy-egy nevének. HóMAN BÁLINT arra vonatkozó vélekedését, hogy a [Saleszé] olvasatú név a török eredetű sarló szóra visszavezethető Sarlós név változatának tekinthetö, a nyelvtörténet oldaláról nehéz megtámogatni. A görög nyelvü emlékekben az $s$ hang legjellemzőbb jelölöje a $\sigma$ volt (GYÓNI 1943: 210, vö. BENKÖ 2003: 11). A Veszprémvölgyi adománylevél is jól illeszkedik ebbe a gyakorlatba (PAIS 1939: 17, 30), ezt példázza

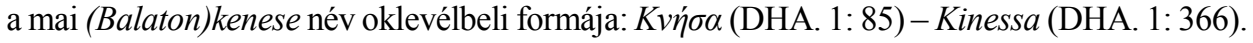
Ezen túlmenően sem könnyü a két névformát azonosítani: problémát okozhat például a szóvégi magánhangzó mibenléte vagy a tőben eredetileg meglévő $r$ hang hiányának magyarázata.

4.3.2. Időben a második értelmezés MIKOS JózSEFtől származik, aki kétségtelennek gondolja, hogy a görög, illetve latin oklevél szórványa nem ugyanaz a név, jóllehet nagy valószínüséggel ugyanazt a falut vagy birtokot jelölte. A görög nyelvü emlékekben nem 
ritka, hogy az $e$ hangot $\alpha$-val jelölik (vö. ehhez még GYÓNI 1943: 209, BENKÖ 2003: 11),

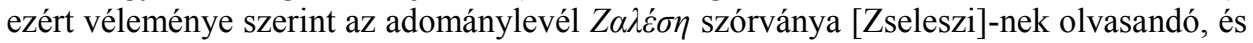
a Zselic erdőnévvel hozható kapcsolatba (MIKOS 1935: 118). A Zselic név meglehetősen bonyolult etimológiájának részletes kifejtése nélkül (ehhez 1. JUHÁsz 1988: 107) azt kell megvizsgálnunk, hogy az oklevélben említett település görögül lejegyzett neve ${ }^{13}$ és a közelben fekvő táj neve kapcsolatban lehet-e egymással. MIKOS szerint a nevek összetartozásának kétféle lehetséges módja is van: 1. az erdőség neve egykor esetleg nagyobb területre vonatkozott; 2. a név személynévi eredetét vallva az előzőnél is valószínübbnek tartja, hogy az erdőnek és a helynek ugyanaz a személy vagy azonos nevü személy volt a birtokosa. Ez utóbbi magyarázatot egyrészt az bizonytalanítja el, hogy a történeti forrásokból nem ismerünk birtoklástörténeti tájneveket, azaz olyan neveket, amelyek az egykori birtokos nevéből erednek, és nagyobb területet jelöltek (vö. HOFFMANN-RÁCZ-TÓTH

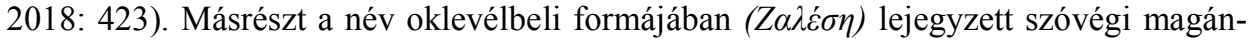
hangzót semmi nem indokolná a névnek a Zselic névvel összefüggő személynévi származtatása esetén. ${ }^{14}$ Fontos azonban megjegyeznünk, hogy a történeti adatok alapján a tájnévvel összefüggő Bars megyei Zseliz (TóTH 2001: 250, Gy. 1: 488-489), illetve a Borsod megyei Ziliz (Póczos 2001: 80, Gy. 1: 817) településnevek vélhetően puszta személynévből származnak.

A MiKos által felvetett első magyarázathoz visszatérve a tájnév településnévi eredete

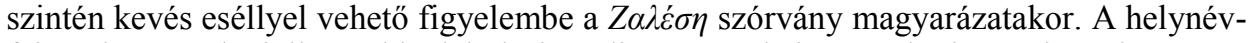
fajtának nem a legjellemzőbb alakulási módja ugyan, de ismerünk olyan tájneveket, amelyek településnévi elözményre vezethetők vissza. Ide sorolhatók például a Bugac, Bakony, Csernec tájnevek (vö. JUHÁSZ 1988: 61, 65, 68). Az azonban már kevésbé illeszkedik a magyar névadási gyakorlathoz, hogy egy, a tájon kívül eső település neve alapján nevezzenek el egy erdőséget, majd tájat. A Zselic elnevezés Somogy megyén túl a Baranya és Tolna megye határán végighúzódó erdős hegyvidékre is vonatkozott egykor (Gy. 1: 247, REUTER 1986: 224, JUHÁSZ 1988: 107, KMHsz. 1: 306), de az a hely (a Pécstől délkeletre elhelyezkedő mai Magyarsarlós), amelyre a görög nyelvü oklevél neve vonatkozott, ma és egykor is kívül esett ezen a területen, nem tartozott tehát a Zselicség településeihez.

4.3.3. PAIS DEZSŐ az oklevélnek mint nyelvemléknek az elemzésekor kétféle lehetséges magyarázatát adja a szórványnak (1939: 37-40).

Az első értelmezés arra a feltételezésre épít, hogy a $\zeta c s$ vagy $c$ hangértékben szerepel a szórványban. GYÓNI MÁTYÁs A magyar nyelv görög feljegyzéses szórványemlékei című nagyszabású munkájában ugyanakkor nem hoz példát arra, hogy a $c$ és $c s$ affrikátákat a dzéta önmagában jelölte volna, e hangok jelölésére a dzétát a tauval $(\tau \zeta)$ együtt volt szokás használni (1943: 210, vö. BENKÖ 2003: 11). A Veszprémvölgyi adománylevélből

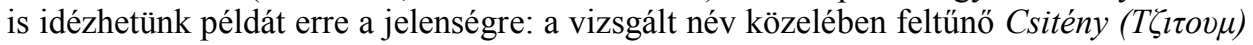
és Gerencsér ( $\Gamma \rho \imath \tau \zeta \zeta \alpha ́ \rho l) ~ h e l y n e v e k e t$ (DHA. 1: 85). PAIS DEZSÖ is megjegyzi, hogy „kissé furcsa ugyan” az egy oklevélen belüli efféle ingadozás, de ez nem akadályozza meg abban, hogy a szórványt - [Csalëszi Calëszi]-nek olvasva - török eredetünek tartsa.

\footnotetext{
${ }^{13}$ Az oklevélben kétségtelenül településnévről van szó: $\chi \omega \rho i ́ \omega v ~ \tau \alpha$ ovó $\mu \alpha \tau \alpha$ (DHA. 1: 85).

${ }^{14}$ A névvégi - $i$ hang kapcsán már GYÓNI MÁTYÁs is megfogalmazta bizonytalanságait: nem dönthető el, hogy ez a hang szláv, illetve szlávból származó szóvégi magánhangzó-e, vagy inkább görögösítő végződés (1943: 54, vö. még DARKó 1917: 259).
} 
A korai ómagyar korban a helyesírás kiforratlan volta miatt általánosan elterjedt volt az, hogy ugyanazt a hangot egy oklevélen belül hol így, hol úgy jelölték, az a körülmény azonban, hogy a dzéta tau nélkül sehol máshol nem fordul elö $c$ vagy $c s$ hangértékben, bizonytalanná teszi az erre támaszkodó magyarázatot.

A török čal 'levág' deverbális képzős származékát látva a névben ('akinek teendője, hivatása, feladata, foglalkozása a vágás, aratás') PAIS DEzső nagyobb bizonyossággal vallja, hogy a görög oklevelet lejegyző ugyanazt a helyet említi, mint száz évvel később a latin változatot készítő írnok. Véleménye szerint ugyanis mind a törökből származó görög oklevélbeli $Z \alpha \lambda \varepsilon ́ \sigma \eta$, mind pedig a latin oklevélbeli magyar Serlous mögött ugyanaz a névadási motívum húzódik meg (1939: 39).

Az a körülmény, hogy jelenleg nem ismerünk biztos példát arra, hogy a görög $\zeta$-val magyar $c s \sim c$ hangot is jelölhettek (a magyar $c s$-t Konsztantinosznál is egyértelmúen a $\tau \zeta$ betủegyüttes jelöli, vö. BENKÖ 2003: 11), meglehetősen ingatag lábakra helyezi ezt az etimológiát. És ha ehhez - a korábban mondottaknak megfelelően - még azt is hozzáveszszük, hogy a latin $z$-vel jelöltek ugyan efféle hangokat a szórványemlékeinkben, de ezekben a hangértékekben messze nem ez volt a leggyakoribb betü (vö. KNIEZSA 1952: 192-193, KOROMPAY 2018: 87), az még tovább fokozhatja a kételyeinket.

A PAIS által kifejtett névmagyarázat értékelését nem befolyásolja ugyan közvetlenül az, hogy a Sarlós nevet valóban tarthatjuk-e társadalmi csoportnévböl alakult helynévnek vagy sem, de e helyütt kívánok rá kitérni, hogy a foglalkozásnévi eredetet valló nézetekkel szemben (vö. HECKENAST 1970: 118; GYÖRFFY 1972: 286, 1977: 240, 1994: 17) megjelentek a Sarlós név efféle származtatását történeti és nyelvi oldalról kétségbe vonó álláspontok is. ${ }^{15}$ SOLYMOSI LÁSZLÓ a Veszprémvölgyi oklevélben említett szolgálónépek összetétele alapján tartja bizonytalannak azt, hogy a latin renovációban szereplő Sarlós falu lakói sarlókészítők voltak, igen kevés iparos van ugyanis köztük (1972: 189). Nyelvi oldalról pedig az a kifogás emelhető a foglalkozásnévi eredet ellen, hogy a sarlós foglalkozást jelentő közszóként nem adatolható a régi magyar nyelvből (RÁCZ 2015: 411, HOFFMANNRÁCZ-TÓTH 2018: 284, vö. KRISTÓ 1976: 71).

4.3.4. A legutolsó lehetséges névmagyarázat ugyancsak PAIS DEZsőnél jelent meg elsőként részletezően azután, hogy az okleveles helynevek szláv elnevezéseit felsorolva MARGALITS EDE is említést tett a Veszprémvölgyi adománylevélben szereplő névről (1902: 555). PAIS a névnek ezt az értelmezését az előbb bemutatottal szemben kevésbé tartotta valószínünek. Mintegy mellékesen jegyezte csak meg, hogy a kérdéses nevet szláv helynévként is értelmezhetjük, amely a szláv $z a$ 'mögött, túl' + lěs b 'erdö' (MIKLOSICH 1886: 399, 167) szavakból származtatható (PAIS 1939: 38). Vele szemben én úgy látom,

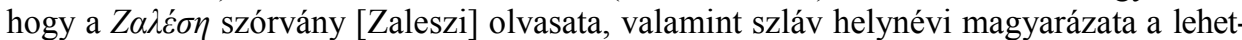
séges etimológiák között a legkevesebb problémát előhozó értelmezés. ${ }^{16}$ A szláv településnévrendszerbe is tökéletesen illeszkedik egy ilyen prepozíciós szerkezetből alakult helynév: vö. cseh Záměl 'zátony mögött[i hely]', szb-hv. Zaslop 'vízesés möge, zúgó mögötti hely'

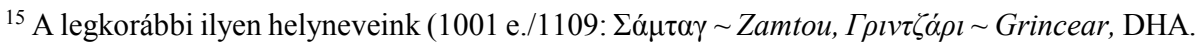
1: 85, 366) ugyanakkor mégis a Veszprémvölgyi oklevélben fordulnak elő (KRISTó 1976: 71-73, 2000b: 39; RÁCZ 2015: 410; HOFFMANN-RÁCZ-TóTH 2018: 282).

${ }^{16}$ A név végi $-i$ hang esetleg a *-jb -ja -je képző folytatása lehet (vö. ŠMILAUER 1970: 112, HOFFMANN-RÁCZ-TóTH 2018: 196-198).
} 
stb. (vö. HOFFMANN-RÁCZ-TÓTH 2018: 201-202). A lěsъ lexémából is több szláv nyelvben alakultak helynévi származékok: vö. cseh Zálesi, lengyel Zalesie (VASMER 1941: 34, ŠMILAUER 1970: 112). A névnek a szláv helynévi származtatását később többen is elfogadták (vö. pl. GYÖRFFY 1977: 321, 1988a: 47-48, 1994: 20; KRISTÓ 2000b: 19-20, 2005: 121, vö. 1993: 202; GÁBOR 2008: 9).

5. Az előző három magyarázatot sem tudjuk ugyan teljes mértékben elvetni, ám mindegyik esetében találtunk legalább egy-egy olyan gyanút keltő körülményt, amely jelentős mértékben megkérdőjelezi a tarthatóságukat. Véleményem szerint leginkább egy olyan szláv eredetü helynévnek kell tartanunk a görög alapítólevélben megjelenő helynevet, amely tartósan nem vált a magyar helynévrendszer elemévé. A névnek ezt az értelmezését az előbbieken túl egyrészt az is támogathatja, hogy szláv nyelvi származtatás esetén a név szemantikai tartalma ('erdőn túl') jól illeszkedik a hely környezetéhez is, az egykori Sarlós (mai Magyarsarlós) ugyanis Baranya megye északi részén, a Zselici erdőségtől délre helyezkedik el (vö. pl. Gy. 1. térképvázlat). Másrészt a mai Magyarsarlós környékéröl több szláv eredetü helynevet is ismerünk (pl. a Nógrád és Szajk településneveket; vö. FNESz.).

A Veszprémvölgyi adománylevél latin renovációjának névhasználata talán már arra utal, hogy a 12. században Sarlós-ként nevezték meg a helyet. Amennyiben a jövőben teljes bizonyítást nyer az, hogy a Pécsváradi alapítólevél Sorlogys szórványa Magyarsarlós település Sarlós nevének a változata, akkor talán még korábbi időkre datálhatjuk azt a változást, amikor a Baranya megyei helynek a szláv nyelvü népektöl kölcsönzött nevét a magyar Sarlós forma váltotta fel. Ugyanakkor a Pécsváradi oklevél magyar névelőfordulása éppenséggel arra is példát mutathat, hogy a 11. század első felében a településnek még egyidejűleg létezhetett az eltérő névadási motívumú szláv és magyar neve, később azonban a szláv formának nincs nyoma a fennmaradt forrásokban.

\section{Hivatkozott irodalom}

BÁRCZI GÉZA 1951. A tihanyi apátság alapitólevele mint nyelvi emlék. Akadémiai Kiadó, Budapest. BÁRCZI GÉZA 1958a. A magyar szókincs eredete. Második kiadás. Tankönyvkiadó, Budapest. BÁRCZI GÉZA 1958b. Magyar hangtörténet. Második, bővített kiadás. Tankönyvkiadó, Budapest. BÉKEFI REMIG 1907. A Balaton környékének egyházai és várai a középkorban. Kilián, Budapest. BENKö LORÁND 1967. A magyar szókészlet eredete. In: BÁRCZI GÉZA - BENKÖ LORÁND - BERRÁR JolÁN, A magyar nyelv története. Nemzeti Tankönyvkiadó, Budapest. 259-351.

BENKÖ LORÁND 2003. Beszélnek a múlt nevei. Tanulmányok az Árpád-kori tulajdonnevekröl. Akadémiai Kiadó, Budapest.

BMFN. = Baranya megye földrajzi nevei. Szerk. PeSti JÁNOS. Baranya Megyei Levéltár, Pécs, 1982.

CzEBE Gyula 1916. A veszprémvölgyi oklevél görög szövege. Értekezések a történeti tudományok köréböl 24: 131-244. [Belső számozás: 1-114.]

Cs. = CSÁNKI DEZSÖ / FEKETE NAGY ANTAL, Magyarország történelmi földrajza a Hunyadiak korában 1-5. MTA, Budapest, 1890-1941.

DARKó JENŐ 1917. A veszprémi apáczamonostor alapító-levelének 1109.-i másolatáról. Egyetemes Filológiai Közlöny 41: 257-272, 336-351.

DF. = Diplomatikai Fényképgyüjtemény. http://mol.arcanum.hu 
DHA. 1. = Diplomata Hungariae antiquissima. Accedunt epistolae et acta ad historiam Hungariae pertinentia 1. Ab anno 1000 usque ad annum 1196. Edendo operi praefuit GEORGIUS GYÖRFFY. Akadémiai Kiadó, Budapest, 1992.

ÉRsZEGI GÉZA 1978-1990. A középkor: Tolna megye a honfoglalástól a mohácsi csatáig. In: K. BALOG JÁNOS szerk., Évszázadokon át. Tolna megye történetének olvasókönyve 1-3. Tolna Megyei Levéltár, Szekszárd. 1: 9-97.

ÉRSZEGi GÉZA 1988. Szent István görög nyelvű okleveléröl. Levéltári Szemle 38: 3-13.

ÉRSZEGI GÉZA 1997. Kálmán király latin nyelvű oklevele. In: GYÖRFFY GYÖRGY föszerk., Árpádkori oklevelek. 1001-1196. Balassi Kiadó, Budapest. 124-125.

EWUng. = Etymologisches Wörterbuch des Ungarischen 1-2. Hrsg. BENKÖ, LoRÁND. Akadémiai Kiadó, Budapest, 1993-1995.

FeJÉRPATAKY LÁSZLÓ 1885. A királyi kanczellária az Árpádok korában. Magyar Tudományos Akadémia, Budapest.

FEJÉRPATAKY LÁSZLÓ 1892. Kálmán király oklevelei. Értekezések a történeti tudományok köréböl 15: 197-281. [Belső számozás: 1-87.]

FNESz. = KISS LAJOS, Földrajzi nevek etimológiai szótára 1-2.4., bővített és javított kiadás. Akadémiai Kiadó, Budapest, 1988.

GÁBOr Olivér 2008. Pécs és Baranya a 9. században. Pécsi Szemle 11: 4-14.

GERSTNER KÁROLY 2018. Szókészlettörténet. In: Kiss JENÖ - PusZTAi FerenC szerk., A magyar nyelvtörténet kézikönyve. Tinta Könyvkiadó, Budapest. 249-270.

Gy. = GYÖRfFY GYÖRGY, Az Árpád-kori Magyarország történeti földrajza 1-4. Akadémiai Kiadó, Budapest, 1963-1998.

GYOMLAY GyULA 1901. Szent István veszprémvölgyi donatiojának görög szövegéröl. Értekezések a nyelv-és széptudományok köréböl 17: 393-434. [Belső számozás: 1-44.]

GYÓNI MÁTYÁs 1943. A magyar nyelv görög feljegyzéses szórványemlékei. Magyar-görög tanulmányok 24. Pázmány Péter Tudományegyetemi Görög Filológiai Intézet, Budapest.

GYÖRFFY GYÖRGY 1956. A tihanyi alapítólevél földrajzinév-azonosításaihoz. In: BÁRCZI GÉZA BENKÖ LORÁND szerk., Emlékkönyv Pais Dezsö hetvenedik születésnapjára. Akadémiai Kiadó, Budapest. 407-415.

GYÖRFFY GYÖRGY 1969. A magyar egyházszervezés kezdeteiről újabb forráskritikai vizsgálatok alapján. MTA Filozófiai és Történettudományok Osztályának Közleményei 18: 199-225.

GYÖRFFY GYÖRGY 1972. Az Árpád-kori szolgálónépek kérdéséhez. Levéltári Szemle 15: 261-320.

GYÖRFFY GYÖRGY 1977. István király és müve. Gondolat, Budapest.

GYÖRFFY GYÖRGY 1988a. István király egyházalapító okleveleiből. In: KIRÁLY LÁSZLÓ szerk., István király emlékezete. Európa Könyvkiadó, Budapest. 43-59.

GYÖRFFY GYÖRGY 1988b. Szent István történeti kutatásunkban. In: GLATZ FERENC-KARDOS JÓZSEF szerk., Szent István és kora. MTA Történettudományi Intézet, Budapest. 18-22.

GYÖRFFY GYÖRGY 1994. A veszprémvölgyi alapítólevél. In: V. FODOR ZsUZSANNA szerk., Veszprém kora középkori emlékei. Felolvasóülések az Árpád-korból 2. Veszprém Megyei Jogú Város Önkormányzata, Veszprém. 16-21.

GYÖRFFY GYÖRGY 1997. Árpád-kori oklevelek. Balassi Kiadó, Budapest.

GYÖRFFY GYÖRGY 2001. Szent István király és a pécsváradi apátság kapcsolata. In: FÜZESI MIKLÓs szerk., Pécsvárad. Pécsvárad Város Önkormányzata, Pécsvárad. 97-101.

H. = Hazai okmánytár 1-8. Kiadják NAGY IMRE et al. etc. Sauervein/Franklin, Győr/Budapest, $1865-1891$. 
HeCKenASt GuSzTÁv 1970. Fejedelmi (királyi) szolgálónépek a korai Árpád-korban. Akadémiai Kiadó, Budapest.

HoFFMANN IsTVÁN 2009. A magyar nyelv hazai szórványemlékei. In: MADAS EDIT szerk., „Látjátok feleim..." Magyar nyelvemlékek a kezdetektől a 16. század elejéig. Országos Széchényi Könyvtár, Budapest. 13-28.

HofFMANN ISTVÁN - RÁCZ ANITA - TÓTH VALÉRIA 2018. Régi magyar helynévadás. A korai ómagyar kor helynevei mint a magyar nyelvtörténet forrásai. Gondolat Kiadó, Budapest.

Holler LÁSzLó 2012. Az 1109. évi veszprémvölgyi ítéletlevél néhány alapkérdéséről. Magyar Nyelv 108: 51-72.

HómAn BÁlint 1911. A veszprémvölgyi 1109. évi oklevél hitelessége. Turul 29: 123-134, 167-174.

HómAN BÁLINT 1917. Szent István görög oklevele. Századok 51: 99-136, 225-242.

HoRvÁT IsTVÁN 1834. Még egykét szó Szent István Királynak Görög Nyelvü Ókleveléröl. Tudományos Gyüjtemény 18: 91-96.

JERNEY JÁNOS 1854. Magyar nyelvkincsek Árpádék korszakából. Szent István Társulat, Pest.

JuHÁsz Dezső 1988. Magyar tájnévadás. Nyelvtudományi Értekezések 126. Akadémiai Kiadó, Budapest.

KARÁCSONYI JÁNOS 1891. Szent István király oklevelei és a Szilveszter bulla. Magyar Tudományos Akadémia, Budapest.

KMHsz. = Korai magyar helynévszótár 1000-1350. 1. Szerk. HofFMANN IsTVÁN. A Magyar Névarchívum Kiadványai. DE Magyar Nyelvtudományi Tanszék, Debrecen, 2005.

KNIEZSA IsTVÁN 1952. Helyesirásunk története a könyvnyomtatás koráig. Akadémiai Kiadó, Budapest.

KorOMPAY KlÁRA 2018. Helyesírás-történet. In: Kiss JeNŐ - PusZTAI Ferenc szerk., A magyar nyelvtörténet kézikönyve. Tinta Könyvkiadó, Budapest. 83-98.

KRISTÓ GyUla 1976. Szempontok korai helyneveink történeti tipológiájához. Acta Historica Szegediensis 55. József Attila Tudományegyetem Bölcsészettudományi Kara, Szeged.

KRISTÓ GYULA 1993. Adatok és szempontok a magyar helynévadás kialakulásához a X-XI. század fordulója táján. Névtani Értesitő 15: 200-205.

KRISTÓ GyUla 2000a. Szent István pécsváradi okleveléröl. In: Piti FerenC - SzABADOS GYörgY szerk., ,Magyaroknak eleiröl." Ünnepi tanulmányok a hatvan esztendös Makk Ferenc tiszteletére. Szegedi Középkorász Mühely, Szeged. 307-321.

KRISTÓ GYULA 2000b. Magyarország népei Szent István korában. Századok 134: 3-44.

KRISTÓ GyUla 2005. Settlement Name Giving in the Age of the Árpáds. Onomastica Uralica 3: $117-133$.

KUMOROVITZ L. BERNÁT 1984. Kálmán király 1109. évi veszprémvölgyi „ítéletlevele”. In: MADARÁsz LAJos szerk., Tanulmányok Veszprém megye múltjából. Veszprém megyei Levéltár, Veszprém. $5-15$.

MARGALiTs EdE 1900-1902. Horvát történelmi repertórium 1-2. Magyar Tudományos Akadémia, Budapest.

MikLOSICH, FrANZ 1886. Etymologisches Wörterbuch der Slavischen Sprachen. Wilhelm Braumüller, Wien.

MiKos JÓZSEF 1935. A veszprémvölgyi görög oklevél két helynevéhez. Magyar Nyelv 31: 116-118

MKFT. = A második katonai felmérés. A Magyar Királyság és a Temesi bánság nagyfelbontású, szines térképei. 1819-1869. Arcanum Adatbázis Kft. DVD., 2005.

MoravCSIK GyUla 1984. Az Árpád-kori magyar történet bizánci forrásai. Fontes Byzantini historiae hungaricae aevo ducum et regum ex stirpe Árpád descendentinum. Akadémiai Kiadó, Budapest. 
MORAVCSIK GyUla - OlAJOS TERÉZIA 1999. A veszprémvölgyi monostor alapítólevele. In: KRISTÓ GYULA szerk., Az államalapitás korának írott forrásai. Szegedi Középkorász Mühely, Szeged. $115-119$.

OLAJOS TERÉZIA 2014. Bizánci források az Árpád-kori magyar történelemhez. Kiegészités Moravcsik Gyula „Az Árpád-kori magyar történet bizánci forrásai” címü forrásgyüjteményéhez. Lectum Kiadó, Szeged.

PAIS Dezsö 1939. A veszprémvölgyi apácák görög oklevele mint nyelvi emlék. A Magyar Nyelvtudományi Társaság Kiadványai 50. Magyar Nyelvtudományi Társaság, Budapest.

Póczos Rita 2001. Az Árpád-kori Borsod és Bodrog vármegye településneveinek nyelvészeti elemzése. Debreceni Egyetem Magyar Nyelvtudományi Tanszéke, Debrecen.

RÁCZ ANITA 2015. A foglalkozásnévi eredetű településnevek történeti tipológiai sajátosságai. In: BÁRTH M. JÁNOS - Bodó CSANÁD - KoCsis ZsuZsAnNA szerk., A nyelv dimenziói. Tanulmányok Juhász Dezső tiszteletére. ELTE BTK Magyar Nyelvtörténeti, Szociolingvisztikai, Dialektológiai Tanszék, Budapest. 410-421.

ReuTER CAMILLO 1986. Élt-e a Zselicség tájnév? Magyar Nyelvőr 110: 223-225.

Šmilauer, VladimíR 1970. Príručka slovanské Toponomastiky. Handbuch der slawischen Toponomastik. Academia, Praha.

SOLYMOSI LÁSZLÓ 1972. Árpád-kori helyneveink felhasználásáról. Magyar Nyelv 68: 179-190.

SZENTGYÖRGYI RUDOLF 2012. A veszprémvölgyi monostor görög nyelvü adománylevele - legelsö hazai nyelvemlékünk? Magyar Nyelv 108: 303-322, 385-399.

SZENTPÉTERY IMRE 1918. Szent István király pécsváradi és pécsi alapitólevele. Magyar Tudományos Akadémia, Budapest.

TESz. = A magyar nyelv történeti-etimológiai szótára 1-3. Főszerk. BENKö LORÁND. Akadémiai Kiadó, Budapest, 1967-1976.

TÓTH VAlÉRIA 2001. Az Árpád-kori Abaúj és Bars vármegye helyneveinek történeti-etimológiai szótára. Debreceni Egyetem Magyar Nyelvtudományi Tanszéke, Debrecen.

VASMER, MAX 1941. Die Slaven in Griechenland. Verlag der Akademie der Wissenschaften, Berlin.

Vat. = Monumenta Vaticana historiam regni Hungariae illustranta. Series I. Tom. 1-6. Szent István Társulat, Budapest, 1885-1891.

WOT. = RÓNA-TAS, ANDRÁS-BERTA, ÁRPÁD, West Old Turkic. Turkic loanwords in Hungarian 1-2. Harrasowitz Verlag, Wiesbaden, 2011.

ZSILINSZKY ÉvA 2005. Szókészlettörténet. Ösmagyar kor. In: KISS JENÖ - PUSZTAI FERENC szerk., Magyar nyelvtörténet. Osiris Kiadó, Budapest. 173-203.

SZÖKE MELINDA

ORCID: https://orcid.org/0000-0003-2726-4973

Debreceni Egyetem

Bölcsészettudományi Kar

\section{Melinda SzőKE, The place name Sorlogys in St. Stephen's Charter of Pécsvárad and its context}

The Benedictine Abbey of Pécsvárad was founded by St. Stephen. The authentic foundation charter of the abbey was presumably completed at the beginning of the $11^{\text {th }}$ century, and it was followed by the authentic registering charter at the end of the century. The originals of these charters 
did not survive separately, only as parts of the fake charter of Pécsvárad. The fake charter of Pécsvárad was written around 1220, using the previously issued charters (e.g. the authentic foundation and registering charters) as sources. The fake charter was not preserved in its original form either, only in multiple transcriptions from the early $15^{\text {th }}$ century. In this study, the author comments on the source value of the fake charter in place-name history, based on the name Sorlogys included in the charter. The author attempts to answer the question whether or not the denotation of the name form can be related to the date of the authentic charter, that is, to the $11^{\text {th }}$ century. In the second part, the study analyses the connection between the place name $Z \alpha \lambda \dot{\varepsilon} \sigma \eta$ in the foundation charter of the nunnery in Veszprémvölgy and the name Sorlogys in the present charter. 